\title{
REVIEW
}

\section{The Clinical Value of Red Blood Cell Distribution Width as a Prognosis Factor and Severity Marker in Sepsis and Septic Shock}

\author{
Emanuel Moisă ${ }^{1}$, Silvius Negoiţă ${ }^{1,2}$, Dan Corneci ${ }^{1,2}$ \\ ${ }^{1}$ Anaesthesiology and Critical Care Department, Elias Clinical Emergency Hospital, \\ Bucharest, Romania \\ 2 Faculty of Medicine, "Carol Davila" University of Medicine and Pharmacy, Bucharest, Romania
}

Correspondence to:

Emanuel Moisă, MD, Department of Anaesthesia and Critical Care, Elias Clinical Emergency Hospital, 17 Marasti Bd, Bucharest, Romania

E-mail: emanuelmoisa@gmail.com

\section{Conflicts of interests}

Nothing to declare

\section{Acknowledgements \\ None}

Funding: This research did not receive any specific grant from funding agencies in the public, commercial or not-for profit sectors.

Keywords: sepsis, septic shock, red blood cell distribution width, mortality, ICU scoring system.

These authors take responsibility for all aspects of the reliability and freedom from bias of the data presented and their discussed interpretation.

Central Eur J Clin Res 2019;2(1):58-66

Received: 29.11.2018, Accepted: 05.01.2019, Published: 05.02.2019

Copyright (C) 2018 Central European Journal of Clinical Research. This is an open-access article distributed under the Creative Commons Attribution License, which permits unrestricted use, distribution, and reproduction in any medium, provided the original work is properly cited.

\section{Abstract}

Red blood cell distribution width (RDW) is a hematological parameter usually measured with every complete blood count. Its place in daily practice is mainly in the differential diagnosis of anemia, but nowadays, researchers are focused on different approaches for the erythrocyte's changes in function and morphology.

Sepsis and its most advanced form, septic shock, induces profound disturbances into organ system's function and morphology. The red blood cells physiology and structure are directly and indirectly altered by these im- balances produced in sepsis. RDW was studied in many diseases, like acute heart failure, acute stroke, inflammatory bowel diseases, chronic lung diseases and cancer, but also in sepsis. Its changes are seen to be mainly associated with prognosis. Higher values of RDW are correlated with mortality and severity of illnes in septic and all-cause critically ill patients. RDW was studied also as an independent variable in different predictive scores and some studies suggest it should be introduced in the scores use on a daily basis in critical care settings and emergency departments.

In this review we will focus on how RDW was associated with mortality and severity of illness in the recent literature, as an independent 
prognosis factor and as a component part in different predictive and severity scores.

\section{Introduction}

Red blood cell distribution width (RDW) represents a hematological parameter measured with every complete blood count. RDW evaluates the red blood cells (RBCs) grade of anisocytosis, which means the variability in erythrocyte's size. RDW is used by clinicians mostly for the differential diagnosis of anemia. In this review we will focus on the changes of RDW in sepsis and septic shock. This easy to obtain tool has become the area of interest for researchers in many disorders [1-3], in terms of mortality, most authors considering it an independent prognosis factor [4,5] or as a part of possible scoring systems [6-8], progression to more severe conditions $[9,10]$ and therapeutic response $[11,12]$.

\section{Possible pathophysiological mechanisms explaining RDW changes in septic patients}

Red blood cells rheological changes can alter RDW in septic patients [13]. Mechanisms of changes in shape (sphericity), volume and deformability are still not completely understood [13], but several have been proposed in septic patients: phosphatidylserine redistribution on the outer red blood cell membrane leaflet $[14,15]$, alterations of RBC sialic acid membrane content $[16,17]$, band 3 protein phosphorylation [18], redox imbalances [19-21], calcium [22], 2,3-diphosphoglycerate [23] and adenosine triphosphate [24] homeostasis alterations and nitric oxide pathway modulation $[25,26]$. Also, inflammatory response indirectly modulates hematopoiesis through abnomal iron metabolism, increased hemolysis and decreased erythrocyte life span which will lead, in turn, to an increased release of the immature forms into the bloodstream [19].

\section{RDW and prognosis in septic patients}

Most of the studies focusing on RDW and prognosis were conducted on all cause critically ill patients [27, 28], including septic patients too. Only several studies have focused on how RDW can predict mortality in septic patients [4-7]. Some authors studied in-hospital mortlity $[4,29]$ while others aimed for the short- $[5,30]$ and long-term prognosis [31].

A retrospective study [4] including 279 patients with septic shock described „RDW as a strong predictor of hospital mortality". Subjects were categorized into quintiles based on RDW value on day 1 of septic shock $(<13.5 \%, 13.5 \%$ to $15.5 \%, 15.6 \%$ to $17.5 \%, 17.5 \%$ to $19.4 \%$, and $>19.4 \%$ ). RDW significantly correlated with mortality across RDW ranges with odds ratio [OR] = $4.6(95 \%$ confidence interval $[\mathrm{Cl}], 1.0-23.4 ; \mathrm{p}=$ $0.06), \mathrm{OR}=8.0(95 \% \mathrm{Cl}, 1.5-41.6 ; \mathrm{p}<0.01), \mathrm{OR}$ $=25.3(95 \% \mathrm{Cl}, 4.3-149.2 ; \mathrm{p}<0.001), \mathrm{OR}=12.3$ (95\% Cl, 2.1-73.3; $p<0.006)$, for RDW given intervals: $13.5 \%$ to $15.5 \%$, RDW $15.6 \%$ to $17.5 \%$, RDW $17.6 \%$ to $19.4 \%$ and RDW > $19.4 \%$, respectively. Mortality across these intervals was studied relative to subjects with RDW $<13.5 \%$. RDW values at ICU admission and its relationship with mortality in the intensive care unit (ICU) was studied in patients with community-acquired intra-abdominal sepsis also [32]. In these patients, RDW had very good discriminatory capacity in predicting ICU mortality with an area under the curve (AUC) estimated by the receiver operating characteristics (ROC) analysis of $0.867(95 \% \mathrm{Cl}, 0.791-0.942)$.

Furthermore, some authors focused on geriatric patients with sepsis and septic shock $[29,33]$. Both studies found a significant correlation between increased RDW and ICU mortality [29] and 30-day mortality [33], respectively, in elderly patients. Wang et al [29] reported a mean age of $81.5 \pm 8.3$, and Kim et al [33] a median age of 78 . The potential problems regarding these studies are related firstly by their type - retrospective, but secondly and most importantly, the studied population. Is it the geriatric population more prone to RDW changes irrespective of sepsis and septic shock? As we discussed above, there are many conditions and disorders that can alter RDW and geriatric population should be taken into account, because elderly patients frequently present not one, but many conditions, and most of them are probably in an advanced stage. Thus, this concept of frailty should be added to any alterations in RDW [34]. Hopefully, RDW changes in geriatric septic patients will significantly correlate with mortality after multivariate analysis will take into account all of these risk factors and RDW will still be correlated with ICU mortality. Wang et al [29], after multivariable adjustment, found that RDW was significantly correlated with ICU mortality (hazard ratio $[\mathrm{HR}]=1.18 ; 95 \% \mathrm{Cl}, 1.03-$ 1.35; $p=0.019$ ).

Jo et al [30] retrospectively studied a cohort of 566 patients with severe sepsis and septic shock (as defined by the old definitions for sepsis). RDW values were classified into tertiles (<14\%, $14.1 \%$ to $15.7 \%,>15.8 \%$ ) and mortality was studied range by range. The authors found 
that RDW was increased in non-survivors and was significantly correlated with 28-day mortality. COX regression analysis revealed that RDW was an independent determinant for 28day mortality: $44.9 \%$ for patients with a RDW > $15.8 \%$ ( $\mathrm{HR}=2.57 ; 95 \% \mathrm{Cl}, 1.53-4.34 ; \mathrm{p}<0.001)$, while patients with a RDW of less than $14 \%$ had a mortality of $13.1 \%$. Also, mean corpuscular volume (MCV) was higher in non-survivors with a mean value of 96.1 femtoliters (fL) (92.5100.4), $\mathrm{p}<0.001$.

Lorente et al [5] conducted a prospective, observational, multicenter study including 297 patients with severe sepsis. The authors found increased RDW values of 15.6, 16.0 and 16.6 at days 1,4 and 8 respectively in non-survivors compared with RDW values of 14.7, 15.2 and 16.0 at days 1,4 and 8 in survivours, respectively. Higher RDW values at day 1, 4 and 8 were significantly correlated with 30 day-mortality ( $p=0.001, p=0.001, p=0.002)$. Malondialdehyde (MDA) as an indicatior of redox imbalance and tumor necrosis factor-alpha (TNF- $\alpha$ ) as a marker of the inflammatory response had the same timing of measuring. RDW was correlated with serum MDA levels at day $1(p<0.001)$ and day $4(p=0.009)$ and serum TNF- $\alpha$ levels at day $4(p=0.002)$ and day $8(p=0.007)$, respectively. These results sug- gest even further that a relation between redox species, inflammatory molecules and RDW exists in sepsis. Kaplan-Meier analysis estimated a $70 \%$ higher risk of mortality for patients with a RDW > 15.5\%.

28-day and 90-day mortality was studied by Kim et al [35]. RDW values were collected at the admission time and their dynamics in the next 72 hours ( $\triangle$ RDW72hr-adm). Patients with increased baseline RDW value and those with an increase of $>0.2 \%$ in the first 72 hours ( $\triangle$ RDW72hr-adm $>0.2 \%$ ) presented the highest risk for 28-day and 90-day mortality.

Finally, long-term prognosis was just recently studied by Han et al [31]. This retrospective observational study used a large critical care database (Medical Information Mart for Intensive Care Medicine III), with a total number of 4264 septic patients being included and their 4-year mortality studied in relationship with baseline RDW values. RDW was independently associated with all-cause mortality in multivariable COX analysis and also, presented moderate discriminatory capacity with an AUC estimated by the ROC analysis of $0.64(95 \% \mathrm{Cl}$, 0.63-0.66). In Table 1 are summarized the main studies of how RDW is changed in septic patients.

Table 1, RDW as an independent prognosis factor and an indicator of illnes severity

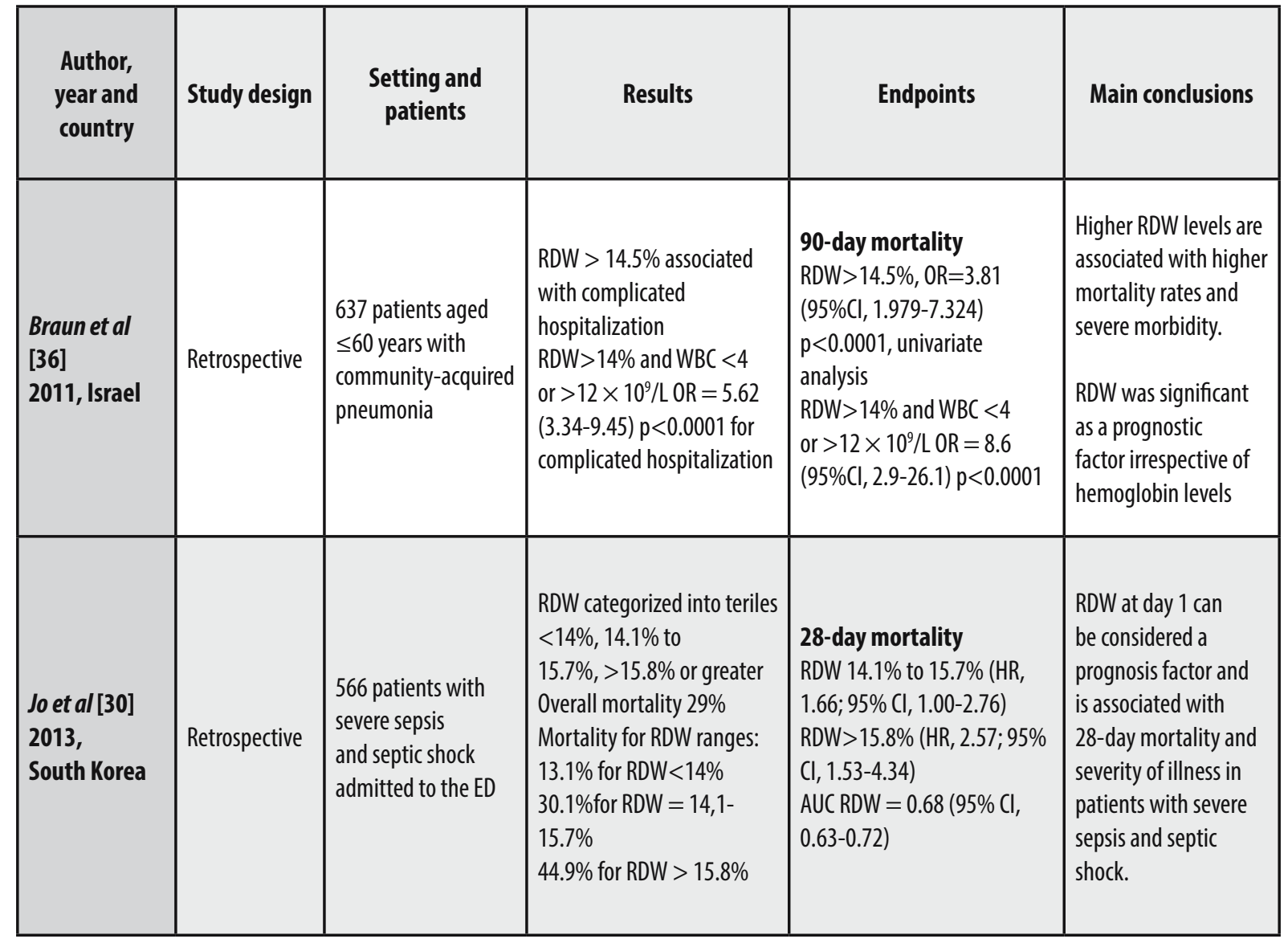




\begin{tabular}{|c|c|c|c|c|c|}
\hline $\begin{array}{l}\text { Sadaka et } \\
\text { al [4] } \\
2012, \text { USA }\end{array}$ & Retrospective & $\begin{array}{l}279 \text { patients } \\
\text { with septic shock } \\
\text { admitted in the ICU } \\
\text { RDW on day } 1 \text { of } \\
\text { septic shock }\end{array}$ & $\begin{array}{l}\text { Quintiles based on RDW: } \\
<13.5 \%, 13.5 \% \text { to } 15.5 \% \text {, } \\
15.6 \% \text { to } 17.5 \%, 17.5 \% \text { to } \\
19.4 \%,>19.4 \% \\
\text { ICU mortality } \\
\text { RDW day } 1=17.6, \\
\text { Nonsurvivours: } 94, \\
p<0.0001 \\
\text { RDW day } 3=18.2, \\
\text { Nonsurvivours: } 63, \\
p<0.0001 \\
\text { RDW day } 7=18.7, \\
\text { Nonsurvivour }=31, \\
p<0.0001\end{array}$ & $\begin{array}{l}\text { Hospital mortality: } \\
13.5 \% \text { to } 15.5 \%(0 \mathrm{R}, 4.6 ; \\
95 \% \mathrm{Cl}, 1.0-23.4 ; \mathrm{P}<0.06) ; \\
\text { RDW 15.6\% to 17.5\% (OR, } \\
8.0 ; 95 \% \mathrm{Cl}, 1.5-41.6 ; \\
\mathrm{p}<0.01) ; \\
\text { RDW } 17.6 \% \text { to } 19.4 \%(0 \mathrm{R}, \\
25.3 ; 95 \% \mathrm{Cl}, 4.3-149.2 ; \\
\text { P<0.001); } \\
\text { RDW }>19.4 \%(0 \mathrm{R}, 12.3 ; 95 \% \\
(\mathrm{Cl}, 2.1-73.3 ; \mathrm{p}<0.006)\end{array}$ & $\begin{array}{l}\text { Increased RDW } \\
\text { at admission } \\
\text { is significantly } \\
\text { associated with ICU } \\
\text { and hospital mortality } \\
\text { Increased RDW } \\
\text { is associated } \\
\text { with incresed } \\
\text { oxidative stress and } \\
\text { proinflammatory } \\
\text { cytokines } \\
\text { The sum of RDW and } \\
\text { APACHE predicted } \\
\text { mortality better }\end{array}$ \\
\hline $\begin{array}{l}\text { Ku et al [37] } \\
2012, \\
\text { South Korea }\end{array}$ & Retrospective & $\begin{array}{l}161 \text { patients with } \\
\text { Gram-negative } \\
\text { bacteremia, tertiary- } \\
\text { care teaching } \\
\text { hospital }\end{array}$ & $\begin{array}{l}\text { RDW ranged } \\
\text { from } 11.7 \% \text { to } 27.4 \% \\
\text { mean, } 14.9 \% \pm 2.3 \%) \text {, } \\
70 \text { patients with } \\
\text { RDW }>14.6 \% \\
\text { Escherichia coli } 50.3 \% \\
\text { Klebsiella pneumoniae } \\
20.5 \%\end{array}$ & 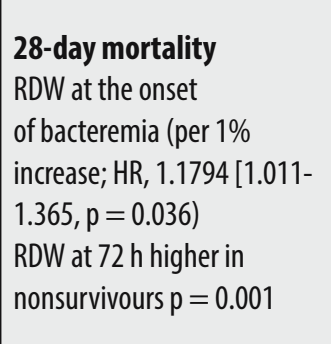 & $\begin{array}{l}\text { RDW at diagnosis } \\
\text { of bacteremia is } \\
\text { an independent } \\
\text { prognosis factor } \\
\text { RDW at } 72 \text { hours is a } \\
\text { predictor of all cause } \\
\text { mortality }\end{array}$ \\
\hline $\begin{array}{l}\text { Kim et al [35] } \\
2013, \\
\text { South Korea }\end{array}$ & Prospective & $\begin{array}{l}329 \text { patients with } \\
\text { severe sepsis } \\
\text { and septic shock } \\
\text { admitted in } \\
\text { the Emergency } \\
\text { Department }\end{array}$ & $\begin{array}{l}\text { Group 1: normal RDW at } \\
\text { baseline and } \triangle R D W 72 \mathrm{hr}- \\
\text { adm } \leq 0.2 \% \text {, } \\
\text { Group 2: increased RDW at } \\
\text { baseline and } \\
\Delta R D W 72 \mathrm{hr} \text {-adm } \leq 0.2 \% \text {, } \\
\text { Group 3: normal RDW at } \\
\text { baseline and } \triangle R D W 72 \mathrm{hr} \text { - } \\
\text { adm }>0.2 \% \\
\text { Group } 4 \text { was made up of } \\
\text { patients } \\
\text { with increased RDW at } \\
\text { baseline and } \triangle R D W 72 \mathrm{hr}- \\
\text { adm }>0.2 \%\end{array}$ & $\begin{array}{l}\text { Primary end-point: } \\
\text { 28-day mortality: } 10 \% \\
\text { Group } 4 \text { after multivariable } \\
\text { adjustment (HR, } 7.85 ; 95 \% \\
\mathrm{Cl} \\
1.63 \text { to } 37.76 ; \mathrm{p}=0.010) \\
\text { Second end-point: } \\
\text { 90-day mortality: } 14.6 \% \\
\text { Group } 4 \text { after multivariable } \\
\text { adjustment }(\mathrm{HR}, 13.74 ; 95 \% \\
\mathrm{Cl}, 2.95 \text { to } 64.10 ; \mathrm{p}=0.001)\end{array}$ & $\begin{array}{l}\text { An increase in } 72 \\
\text { hours of RDW from } \\
\text { baseline is associated } \\
\text { with poor prognosis } \\
\text { A combination } \\
\text { between increased } \\
\text { baseline and } 72 \text { hours } \\
\text { RDW values can be } \\
\text { an independent } \\
\text { prognosis factor }\end{array}$ \\
\hline $\begin{array}{l}\text { Lee et al [38] } \\
2013, \\
\text { South Korea }\end{array}$ & Retrospective & $\begin{array}{l}744 \text { patients } \\
\text { with community- } \\
\text { acquired pneumonia } \\
\text { admitted in the ED }\end{array}$ & $\begin{array}{l}\text { Quartile } \\
\text { RDW <13.3 }(n=196) \\
\text { RDW 13.3-14.1 }(n=172) \\
\text { RDW 14.1-15.2 }(n=190) \\
\text { RDW } \geq 15.2(n=186)\end{array}$ & $\begin{array}{l}\text { 30-day mortality } \\
\text { RDW } \geq 15.2,0 R=2.37,1.04- \\
5.42, p<0.040\end{array}$ & $\begin{array}{l}\text { Admission RDW } \\
\text { values are associated } \\
\text { with 30-day mortality, } \\
\text { length of hospital } \\
\text { stay, and } \\
\text { the use of } \\
\text { vasopressors in } \\
\text { patients with CAP } \\
\text { RDW added to PSI } \\
\text { or CURB-65 severity } \\
\text { scales performed } \\
\text { better as prognosis } \\
\text { markers }\end{array}$ \\
\hline
\end{tabular}




\begin{tabular}{|c|c|c|c|c|c|}
\hline $\begin{array}{l}\text { Lorente et } \\
\text { al [5] } \\
2014 \text {, Spain }\end{array}$ & $\begin{array}{l}\text { Prospective, } \\
\text { observational, } \\
\text { multicenter }\end{array}$ & $\begin{array}{l}297 \text { patients with } \\
\text { severe sepsis from } \\
\text { six Spanish Intensive } \\
\text { Care Units }\end{array}$ & $\begin{array}{l}\text { RDW day } 1=15.7, \\
\text { Nonsurvivours: } 104, \\
p=0.001 \\
\text { RDW day } 4=16.0, \\
\text { Nonsurvivours: } 77, p=0.001 \\
\text { RDW day } 8=16.6, \\
\text { Nonsurvivour }=60, \\
p=0.002\end{array}$ & $\begin{array}{l}\text { 30-day mortality } \\
\text { RDW at day } 1: 0 R=1.13, \\
95 \% \mathrm{Cl} 1.05-1.22, p=0.001 \\
\text { RDW at day } 4: 0 R=1.11, \\
95 \% \mathrm{Cl}, 1.03-1.21, p=0.01 \\
\text { RDW at day } 8: 0 R=1.10 \\
95 \% \mathrm{Cl}, 1.01-1.21, p=0.04\end{array}$ & $\begin{array}{l}\text { RDW during the } \\
\text { first week is correlated } \\
\text { with sepsis severity } \\
\text { and mortality and also } \\
\text { with MDA and TNF-a } \\
\text { levels }\end{array}$ \\
\hline $\begin{array}{l}\text { Ozdogan et al } \\
\text { [32] } \\
\text { 2015, Turkey }\end{array}$ & Retrospective & $\begin{array}{l}103 \text { patients with } \\
\text { community-acquired } \\
\text { intra-abdominal } \\
\text { sepsis admitted in } \\
\text { the ICU }\end{array}$ & $\begin{array}{l}\text { Overall mortality }=50.5 \% \\
\text { RDW at day } 1 \text { higher in } \\
\text { non-survivours }\end{array}$ & $\begin{array}{l}\text { ICU mortality } \\
\text { AUC RDW at day } 1=0.867 \\
(95 \% \text { Cl, } 0.791-0.942)\end{array}$ & $\begin{array}{l}\text { Increased RDW is } \\
\text { an independent } \\
\text { prognosis factor in } \\
\text { patients with C-IAS }\end{array}$ \\
\hline $\begin{array}{l}\text { Kim et al [33] } \\
2015, \text { South } \\
\text { Korea }\end{array}$ & Retrospective & $\begin{array}{l}458 \text { elderly patients } \\
\text { aged }>65 \text { years } \\
\text { with severe sepsis } \\
\text { or septic shock } \\
\text { from a single } \\
\text { tertiary emergency } \\
\text { department }\end{array}$ & $\begin{array}{l}\text { For each } 1 \% \text { increase in } \\
\text { RDW, the } 30 \text {-day mortality } \\
\text { risk increased by } 15 \%\end{array}$ & $\begin{array}{l}\text { 30-day mortality } \\
\text { Independent predictor } \\
(\mathrm{HR}, 1.10 ; 95 \% \mathrm{Cl}, 1.0-1.17 ; \\
\mathrm{p}<0.001)\end{array}$ & $\begin{array}{l}\text { Higher RDW values } \\
\text { are associated with } \\
\text { 30-day mortality in } \\
\text { elderly patients with } \\
\text { severe sepsis and } \\
\text { septic shock }\end{array}$ \\
\hline $\begin{array}{l}\text { Wang et al } \\
{[29]} \\
\text { 2017, Taiwan }\end{array}$ & Retrospective & $\begin{array}{l}117 \text { elderly patients } \\
\text { aged } \geq 65 \text { years } \\
\text { with severe sepsis } \\
\text { and/or septic shock } \\
\text { admitted in ICU }\end{array}$ & $\begin{array}{l}\text { Subgroup analysis } \\
\text { Mortality of patients with } \\
\text { qSOFA }<2 \text { : } \\
\text { non-survivors had higher } \\
\text { RDW levels than survivors } \\
(17.0 \pm 3.3 \% \text { versus } 15.3 \pm \\
1.4 \%, p= \\
0.044)\end{array}$ & $\begin{array}{l}\text { ICU mortality } \\
\text { RDW was an independent } \\
\text { variable for mortality: } \\
\text { HR, } 1.18 \text { [1.03-1.35] for } \\
\text { each } 1 \% \text { increase in RDW, } \\
p=0.019 \text { after multivariable } \\
\text { adjustment }\end{array}$ & $\begin{array}{l}\text { RDW predicted } \\
\text { independently in- } \\
\text { hospital } \\
\text { mortality in elderly } \\
\text { patients with sepsis. } \\
\text { In patients with } \\
\text { qSOFA scores < 2, an } \\
\text { increased RDW value } \\
\text { was associated with } \\
\text { poor prognosis. }\end{array}$ \\
\hline $\begin{array}{l}\text { Han et al [31] } \\
2018 \text {, China \& } \\
\text { Italy }\end{array}$ & Retrospective & $\begin{array}{l}\text { Based o a large } \\
\text { critical care } \\
\text { database; } 4264 \\
\text { subjects with severe } \\
\text { sepsis admitted in } \\
\text { the ICU }\end{array}$ & $\begin{array}{l}\text { Group1: } \\
\text { RDW } \leq 13.9 \text {, Mortality = } \\
31.20 \% \\
\text { Group 2: } \\
\text { RDW between } 14.0 \text { and } \\
15.5 \\
\text { Mortality = } 45.94 \% \\
\text { Group 3: } \\
\text { RDW } \geq 15.6 \text { Mortality = } \\
60.60 \%\end{array}$ & $\begin{array}{l}\text { 4-years mortality } \\
\text { HR of RDW between } 1.13 \\
\text { and } 1.16 \text {, } \\
\text { independently of all severity } \\
\text { scores }(p<0.01 \text { for all) after } \\
\text { multivariable adjustment }\end{array}$ & $\begin{array}{l}\text { Increased RDW in } \\
\text { patients with severe } \\
\text { sepsis is associated } \\
\text { with poor long-term } \\
\text { prognosis } \\
\text { RDW improved } \\
\text { predictive accuracy of } \\
\text { conventional severity } \\
\text { scores }\end{array}$ \\
\hline \multicolumn{6}{|c|}{ 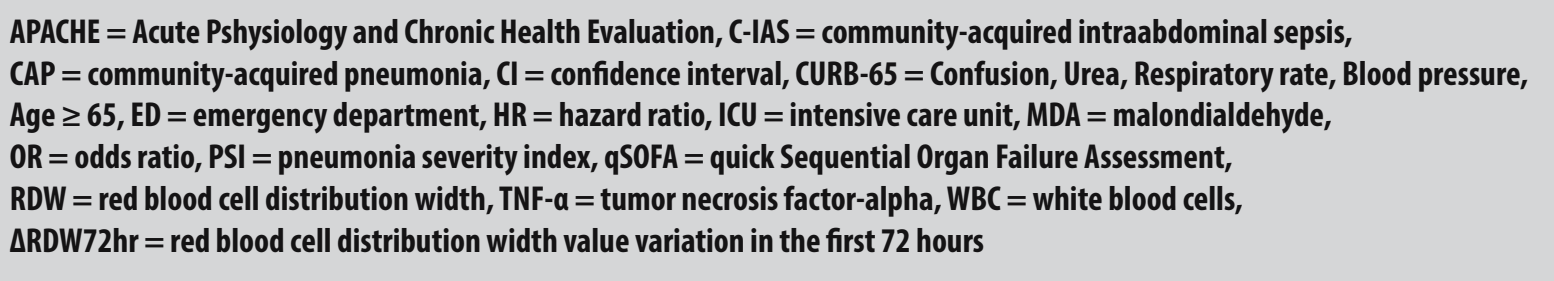 } \\
\hline
\end{tabular}




\section{Further research should focus on introducing RDW as an independent variable in predictive scores used for septic patients}

Predictive scores such as Acute Physiology and Chronic Health Evaluation II (APACHE II), Sequential Organ Failure Assesment (SOFA), Simplified Acute Physiology Score (SAPS II) and others, are routinely used in the critical care settings. These scores are correlated not only with the prognosis, but also with the severity of illnes in ICU patients. Until now, RDW was described mostly in terms of mortality as an independent prognosis factor. Added to these scores, RDW had proof to increase not only their predictive value [4,30], but sepsis severity also [39].

\section{RDW as an indepedent variable in different proposed severity scores for septic patients}

A predictive score in patients with suspected sepsis based on a PIRO concept (Predisposition, Infection, Response and Organ dysfunction) was developed by Chen et al [6]. The study included 7011 patients in the derivation cohort and 12,110 in the validation cohort. This score was named CHARM, each letter corresponding to the independent predictors for mortality identified: Chills, Hypothermia, Anemia, RDW and history of Malignancy. RDW was an independent predictor for mortality with an OR $=3.27(95 \% \mathrm{Cl}, 2.63-4.05 ; \mathrm{p}<0.001)$. This score has good discriminatory capacity with an $A \cup C=0.77(95 \% \mathrm{Cl}, 0.75-0.79 ; p=0.05)$. Sensitivity and negative predictive value for this score were almost perfect with values of $99.4 \%$ and $99.7 \%$ respectively. Furthermore, CHARM score had better predictive capacity than other scores such as Mortality in Emergency Department Sepsis (MEDS), PIRO, CURB-65 (Confusion, Urea, Respiratory rate, Blood pressure, Age $\geq 65$ ), Systemic Inflammatory Syndrome (SIRS) and biomarkers like C-reactive protein, lactate and procalcitonin.

Recently, Kim et al [7] used only hematological parameters and described a predictive score for patients with severe sepsis and septic shock in a retrospective study including 730 patients. Three models have been developed, including RDW value, platelet count and the delta neutophil index (DNI). In the first model, 1 point was given if $\mathrm{RDW}>14.5 \%$, or $\mathrm{DNI}>$ $5 \%$, or platelet count $<150.000 / \mathrm{mm} 3$. A maximum value of 3 was significantly correlated with mortality $(\mathrm{HR}=20.6$; 95\% Cl, 7.2296-58.871; $p<0.001)$, while a score equal with 1 was not $(p$ $=0.128)$. In the second model, DNI and platelet count were subdivided in different value ranges and points were assigned according to these intervals. A score $\geq 2$ was significantly associated with 28-day mortality $(\mathrm{HR}=5.166 ; 95 \% \mathrm{Cl}$, 1.7372-15.362; $p=0.0003)$, with a maximum value of 7 points $(\mathrm{HR}=43.783$; $95 \% \mathrm{Cl}, 9.7906$ $195.797 ; p<0.0001$. This score presented good discriminatory power with a ROC curve (AUC) of $0.785(95 \% \mathrm{Cl}, 0.736-0.833 ; \mathrm{p}<0.001)$ and performed better than lactate $(A \cup C=0.724$; 95\% Cl: 0.666-0.782; $\mathrm{p}<0.001)$ and SOFA score $(A \cup C=0.738 ; 95 \% \mathrm{Cl}, 0.683-0.794 ; p<0.001)$.

Yeh et al [8] described a new predictive score for patients with bacteriemia admitted in the emergency department derived from a PIRO model. RDW was included as an independent variable and 2 points were assigned for a RDW value higher than $15 \%$. The AUC of this new score was $0.88(95 \% \mathrm{Cl}, 0.848-0.913)$, having better discriminatory power than Pitt bacteremia score (AUC 0.750; 95\% Cl, 0.699$0.800 ; p<0.001)$.

\section{RDW relation with ICU and ED scoring systems}

In several studies, the relation between RDW value of septic patients and their predictive scores was studied. In one study, RDW had better discriminative power than APACHE and SOFA (AUCRDW=0.74 versus $A U C A P A C H E=0.69$ versus $A U C S O F A=0.69$ ), but when RDW was added to APACHE, the discriminative power was better than these variables taken alone (AUCRDW+APACHE=0.77) [4]. APACHE II and SOFA were observed to increase with increasing values of RDW [30]. Moreover, DeBari et al [39] found a correlation between RDW value and APACHE II value. Henceforth, a RDW $\geq 16$ significantly correlated with an APACHE II $\geq 15$, authors concluding that septic patients with $\mathrm{RDW} \geq 16$ posibbly have higher severity of illness. Also, dynamic changes of RDW in the first 72 hours performed better in predicting death than SOFA score (AUC $0.802 ;(95 \% \mathrm{Cl}, 0.703-0.901 ; \mathrm{p}<0.001)$ versus 0.703 (95\% Cl, 0.552-0.855; $p=0.008)$ [35].

In patients with community-acquired pneumonia, RDW added to CURB-65 and Pneumonia Severity Index (PSI) scores increased AUC marginally: AUCCURB-65 = $0.74(95 \% \mathrm{Cl}$, $0.69-0.79)$ versus AUCCURB-65+RDW $=0.79$ $(95 \% \mathrm{Cl}, 0.75-0.84)$ and AUCPSI $=0.74(95 \%$ $\mathrm{Cl}, 0.70-0.79)$ versus $\mathrm{AUCPSI+RDW}=0.79$ (95\% Cl, 0.75-0.83) [38]. In another study, RDW 
discriminative power was useful in patients with a qSOFA $<2$ in terms of prognosis [29]. Added to SAPS II, RDW increased the predictive capacity for long-term prognosis in septic patients [31].

\section{Conclusions}

Red blood cell distibution width value in sepsis and septic shock can be a very good independent prognosis factor and also a measurement we should take into considerantion in terms of illness severity. Future studies are needed in order to find the right place for RDW in the ICU and ED scoring systems, but the past research gives us many perspectives on how we should look at this simple paraclinical tool. The dysregulated response induced by the host in sepsis is generalized and part of the homeostasis imbalances are reflected by erythrocyte's abnormal function and morphology. Maybe it is the time we should start seeing red blood cells as more than just anucleated cells responsible for oxygen transport, but as a more complex system.

\section{Abbreviations}

APACHE = Acute Pshysiology and Chronic Health Evaluation, AUC = area under the curve, C-IAS = community-acquired intraabdominal sepsis, CAP = community-acquired pneumonia, $\mathrm{Cl}=$ confidence interval, CURB65 = Confusion, Urea, Respiratory rate, Blood pressure, Age $\geq 65$, DNI = delta neutrophil index, ED = emergency department, $\mathrm{HR}=$ hazard ratio, $\mathrm{ICU}=$ intensive care unit, $\mathrm{MCV}=$ mean corpuscular volume, MDA = malondialdehyde, Mortality in Emergency Department Sepsis = MEDS, OR = odds ratio, PIRO = Predisposition, Infection, Response and Organ dysfunction, $\mathrm{PSI}=$ pneumonia severity index, qSOFA = quick Sequential Organ Failure Assessment, RBC = red blood cell, RDW = red blood cell distribution width, ROC = receiver operating characteristics, SAPS II = Simplified Acute Physiology Score II, SIRS = Systemic Inflammatory Response Syndrome, SOFA = Sequential Organ Failure Assessment, TNF- $\alpha=$ tumor necrosis factor-alpha, $\mathrm{WBC}=$ white blood cells, $\triangle \mathrm{RDW} 72 \mathrm{hr}=$ red blood cell distribution width value variation in the first 72 hours

\section{References}

1. van Kimmenade $\mathrm{R}$, Mohammed $\mathrm{A}$, Uthamalingam S, van der Meer P, Felker G,
Januzzi J. Red blood cell distribution width and 1-year mortality in acute heart failure. European Journal of Heart Failure. 2010;12(2):129-136.

2. Ani C, Ovbiagele B. Elevated red blood cell distribution width predicts mortality in persons with known stroke. Journal of the Neurological Sciences. 2009;277(1-2):103-108.

3. Perlstein T, Weuve J, Pfeffer M, Beckman J. Red Blood Cell Distribution Width and Mortality Risk in a Community-Based Prospective Cohort. Archives of Internal Medicine. 2009;169(6):588.

4. Sadaka F, O'Brien J, Prakash S. Red Cell Distribution Width and Outcome in Patients With Septic Shock. Journal of Intensive Care Medicine. 2012;28(5):307-313.

5. Lorente L, Martín M, Abreu-González P, Solé-Violán J, Ferreres J, Labarta L et al. Red Blood Cell Distribution Width during the First Week Is Associated with Severity and Mortality in Septic Patients. PLoS ONE. 2014;9(8):e105436.

6. Chen K, Liu S, Li C, Wu C, Chaou C, Tzeng I et al. Development and validation of a parsimonious and pragmatic CHARM score to predict mortality in patients with suspected sepsis. The American Journal of Emergency Medicine. 2017;35(4):640-646.

7. Kim Y, Song J, Kim E, Choi H, Jeong W, Jung I et al. A Simple Scoring System Using the Red Blood Cell Distribution Width, Delta Neutrophil Index, and Platelet Count to Predict Mortality in Patients With Severe Sepsis and Septic Shock. Journal of Intensive Care Medicine. 2018;34(2):133-139.

8. Yeh C, Chen K, Ye J, Huang C. Derivation of a clinical prediction rule for bloodstream infection mortality of patients visiting the emergency department based on predisposition, infection, response, and organ dysfunction concept. Journal of Microbiology, Immunology and Infection. 2014;47(6):469477.

9. Xiao C, Wan J, Liu H, Qiu L, Wang F, Liu $S$ et al. Red blood cell distribution width is an independent risk factor in the prediction of acute respiratory distress syndrome after severe burns. Burns. 2019;

10. van Koeverden I, den Ruijter H, Scholtes V, G. E. H. Lam M, Haitjema S, Buijsrogge M et al. A single preoperative blood test predicts postoperative sepsis and pneumonia after coronary bypass or open aneurysm surgery. European Journal of Clinical Investigation. 2019;49(3):e13055.

11. Teng J, Pourmand A, Mazer-Amirshahi M. Vitamin C: The next step in sepsis 
management?. Journal of Critical Care. 2018;43:230-234.

12. Natarajan R. Impact of Intravenous Ascorbic Acid Infusion on Novel Biomarkers in Patients with Severe Sepsis. Journal of Pulmonary \& Respiratory Medicine. 2014;04(06).

13. Bateman $R$, Sharpe $M$, Singer $M$, Ellis $C$. The Effect of Sepsis on the Erythrocyte. International Journal of Molecular Sciences. 2017Aug;18(9):1932.

14. Dinkla S, Eijk LTV, Fuchs B, Schiller J, Joosten I, Brock R, et al. Inflammation-associated changes in lipid composition and the organization of the erythrocyte membrane. BBA Clinical. 2016;5:186-92.

15. Qadri SM, Bissinger R, Solh Z, Oldenborg $P-A$. Eryptosis in health and disease: $A$ paradigm shift towards understanding the (patho)physiological implications of programmed cell death of erythrocytes. Blood Reviews. 2017;31(6):349-61.

16. Piagnerelli M, Boudjeltia KZ, Brohee D, Piro $\mathrm{P}$, Carlier E, Vincent J-L, et al. Alterations of red blood cell shape and sialic acid membrane content in septic patients. Critical Care Medicine. 2003;31(8):2156-62.

17. Piagnerelli $M$, Vincent J-L, Boudjeltia KZ, Brohee D, Vanhaeverbeek M. Modifications of Red Blood Cell Shape and Glycoproteins Membrane Content in Septic Patients. Advances in Experimental Medicine and $\mathrm{Bi}$ ology Oxygen Transport To Tissue XXIII. 2003;:109-14.

18. Condon MR, Feketova E, Machiedo GW, Deitch EA, Spolarics Z. Augmented erythrocyte band-3 phosphorylation in septic mice. Biochimica et Biophysica Acta (BBA) - Molecular Basis of Disease. 2007;1772(5):5806.

19. Ghaffari S. Oxidative Stress in the Regulation of Normal and Neoplastic Hematopoiesis. Antioxidants \& Redox Signaling. 2008;10(11):1923-1940.

20. Yerer MB, Yapislar H, Aydogan S, Yalcin O, Baskurt O. Lipid peroxidation and deformability of red blood cells in experimental sepsis in rats: The protective effects of melatonin. Clinical Hemorheology and Microcirculation. 2004;30(2):77-82

21. Oliveira YPAD, Pontes-De-Carvalho LC, Couto RD, Noronha-Dutra AA. Oxidative stress in sepsis. Possible production of free radicals through an erythrocyte-mediated positive feedback mechanism. The Brazilian Journal of Infectious Diseases. 2017;21(1):19-26

22. Ruef $P$, Ehrhard M, Frommhold D, Koch L, Fritzsching $\mathrm{B}$, Poeschl J. Lipid a decreas- es human erythrocytes deformability by increasing intracellular $\mathrm{Ca} 2+$ : Effects of verapamil, staurosporine and the rho-kinase inhibitor Y-27632. Clinical Hemorheology and Microcirculation. 2011;49:315-322.

23. Lin X, Rogers S, Timm D, Angelo A, Jaya $P$, Melanie E et al. Sepsis Induced Red Cell Dysfunction (SiRD): Physiology and Mechanisms. 2017 dec;130(1):3469

24. Forsyth AM, Wan J, Owrutsky PD, Abkarian $\mathrm{M}$, Stone HA. Multiscale approach to link red blood cell dynamics, shear viscosity, and ATP release. Proceedings of the National Academy of Sciences. 2011;108(27):10986-91.

25. Bateman RM, Sharpe MD, Jagger JE, Ellis CG. Sepsis impairs microvascular autoregulation and delays capillary response within hypoxic capillaries. Critical Care. 2015May;19(1).

26. Winkler MS, Kluge S, Holzmann M, Moritz E, Robbe L, Bauer A, et al. Markers of nitric oxide are associated with sepsis severity: an observational study. Critical Care. 2017;21(1).

27. Zhang Z, Xu X, Ni H, Deng H. Red cell distribution width is associated with hospital mortality in unselected critically ill patients. Journal of Thoracic Disease 2013;5(6):

28. Bazick H, Chang D, Mahadevappa K, Gibbons F, Christopher K. Red cell distribution width and all-cause mortality in critically ill patients*. Critical Care Medicine. 2011;39(8):1913-1921.

29. Wang A, Ma H, Kao W, Tsai S, Chang C. Red blood cell distribution width is associated with mortality in elderly patients with sepsis. The American Journal of Emergency Medicine. 2018;36(6):949-953.

30. Jo Y, Kim K, Lee J, Kang C, Kim T, Park H et al. Red cell distribution width is a prognostic factor in severe sepsis and septic shock. The American Journal of Emergency Medicine. 2013;31(3):545-548.

31. Han Y, Zhang L, Yan L, Li P, Ouyang P, Lippi $G$ et al. Red blood cell distribution width predicts long-term outcomes in sepsis patients admitted to the intensive care unit. Clinica Chimica Acta. 2018;487:112-116

32. Kaya Ozdogan H. Red Cell Distribution Width is Predictive of Mortality in Intensive Care Patients with community-acquired Intra-abdominal Sepsis. Turkish Journal of Trauma and Emergency Surgery. 2015; 21(5): 352-357.

33. Kim S, Lee K, Kim I, Jung S, Kim M. Red cell distribution width and early mortality in elderly patients with severe sepsis and septic shock. Clinical and Experimental Emer- 
gency Medicine. 2015;2(3):155-161.

34. Fraenkel P. Anemia of Inflammation. Medical Clinics of North America. 2017;101(2):285296.

35. Kim C, Park J, Kim E, Han J, Han J, Choi J et al. An increase in red blood cell distribution width from baseline predicts mortality in patients with severe sepsis or septic shock. Critical Care. 2013;17(6):R282.

36. Braun E, Domany E, Kenig Y, Mazor Y, Makhoul B, Azzam Z. Elevated red cell distribution width predicts poor outcome in young patients with community acquired pneumonia. Critical Care. 2011;15(4):R194.

37. Ku N, Kim H, Oh H, Kim Y, Kim M, Song $\mathrm{J}$ et al. Red Blood Cell Distribution Width
Is an Independent Predictor of Mortality in Patients With Gram-Negative Bacteremia. Shock. 2012;38(2):123-127.

38. Lee J, Chung H, Kim K, Jo Y, Rhee J, Kim $Y$ et al. Red cell distribution width as a prognostic marker in patients with community-acquired pneumonia. The American Journal of Emergency Medicine. 2013;31(1):72-79.

39. DeBari V, Mahmood N, Mathew J, Kang $B$, Khan M. Broadening of the red blood cell distribution width is associated with increased severity of illness in patients with sepsis. International Journal of Critical IIIness and Injury Science. 2014;4(4):278. 